\title{
Inhibition of Hageman Factor Activation
}

\author{
H. L. Nossel, H. Rubin, M. Drinlings, and R. HsieH \\ From the Department of Medicine, Columbia University, College of Physicians \\ and Surgeons, New York 10032
}

A B S T R A C T A method for studying inhibitors of the contact stages of blood coagulation is described. A number of positively charged substances were shown to inhibit the contact stages. The inhibitory substances include spermine, cytochrome $c$, ribonuclease, and lysozyme. The inhibitory effect of these substances was neutralized by the addition of an activated plasma thromboplastin antecedent, factor XI, (PTA) fraction. Other positively charged substances including protamine, hexadimethrine, polylysine, polyornithine, methylene blue, and ortho-toluidine blue also inhibited the contact stages of coagulation, but the inhibitory effect on coagulation was not neutralized by the activated PTA fraction. Negatively charged substances such as heparin and insulin did not inhibit the contact stages of coagulation.

Cytochrome $c$ inhibited Celite adsorption of a partially purified Hageman factor fraction, and cytochrome, ribonuclease, spermine, and lysozome inhibited the adsorption of Hageman factor from PTA-deficient plasma. Very much smaller quantities of Celite completely adsorbed Hageman factor from the fraction rather than from whole plasma, which suggested the possibility that plasma contains an inhibitor or inhibitors of Hageman factor adsorption.

Furthermore cytochrome $c$, spermine, ribonuclease, and lysozyme inhibited the coagulant activity of the following activators of the Hageman and PTA factors: Celite, kaolin, sodium stearate, ellagic acid, and skin. It is suggested that negatively charged sites on these activators are critical for adsorption and activation and that inhibition results from neutralization of the negatively charged sites by the adsorbed inhibtor. Tests with polylysine polymers indicate that inhibitory activ-

Received for publication 1 November 1967 and in revised form 7 December 1967. ity is directly related to molecular size over the molecular weight range of 4000 to 100,000 .

\section{INTRODUCTION}

Blood coagulation can be initated by contact with surfaces which include silica compounds, ellagic acid, sodium stearate, human skin, and collagen (1). The initiating stimulus is mediated by the plasma proteins Hageman factor (factor XII) and plasma thromboplastin antecedent (PTA, factor $\mathrm{XI})$. The circumstances under which such activation occurs in vivo are unknown and the physical properties responsible for the coagulant activity of activators are undefined, although the importance of wettability (2) and of negative charge (3) have been postulated. Investigation of these problems may be facilitated by the use of specific inhibitors. Previous personal observation suggested that quaternary ammonium ion detergents might inhibit surface activity, and Haanen, Hommes, and Morselt (4) suggested that glass coated with protamine does not activate Hageman factor. Starting with these observations we will report in the present study the development of tests for studying inhibitors of the contact phase of blood coagulation, describe a number of substances that were found to have inhibitory activity and demonstrate their mode of action.

\section{METHODS}

Silicone-treated glass tubes and pipettes and polystyrene tubes for blood collection were used. Glass tubes $(10 \times 75$ $\mathrm{mm}$ I.D.) were coated twice with $10 \%$ Siliclad (ClayAdams, Inc., New York) and baked 1 hr at $80^{\circ} \mathrm{C}$ after each coating. The tubes were used once for clotting and discarded. Normal, noncontact, platelet-poor plasma (10,0000-20,000 platelets per $\left.\mathrm{mm}^{3}\right)$ (5) and $0.145 \mathrm{M}$ saline buffered with barbital acetate at $\mathrm{pH} 7.40$ were prepared as previously described (7). Untreated Celite 512 (Johns-Manville, New York) was used for making elu- 
ates. Cephalin prepared by the method of Bell and A1ton (6) was used in a $1 / 100$ dilution in saline. Calcium chloride (J. T. Baker Chemical Co., Phillipsburg, N. J.) was dissolved in distilled water to the required molarity. Thromboplastin was an extract of human brain made as described by Biggs and Macfarlane (7) and the thrombin preparation (Fibrindex) was of human origin and supplied by Ortho, Raritan, N. J.

The chemicals used were obtained from the following suppliers: Cohn fractions I-VI, lysozyme $(3 \times$ crystallized), arginine monochloride, tyrothricin, gramicidin, DL-lysine hydrochloride, ribonuclease $(3 \times$ crystallized $)$, and cytochrome $c$ (equine heart) from Nutritional Biochemicals Corporation, Cleveland, Ohio; spermine tetrahydrochloride and papain from Calbiochem, Los Angeles, Calif.; poly-DL-lysine and poly-DL-ornithine from GallardSchlesinger Chemical Mfg. Corp., Carle Place, New York. Graded poly-L-lysine polymers were obtained from Miles Chemical Co., Elkhart, Ind. Three polymers, $2000-6000,30,000-50,000$, and $80,000-120,000 \mathrm{~mol} \mathrm{wt}$, were used. $4000,40,000$ and $100,000 \mathrm{~mol} \mathrm{wt}$, respectively, were used to calculate molar concentration. $\alpha$-Chymotrypsinogen and trypsinogen were obtained from C. F. Boehringer and Sons, Mannheim, Germany; heparin sodium from Upjohn Co.; hexadimethrine bromide (polybrene) from Abbott Laboratories, Chicago, Ill.; protamine sulfate from Eli Lilly \& Co., Indianapolis, Ind.; cetyl trimethylammonium bromide, 3,7-bis (dimethylamino) phenazathionium chloride (methylene blue) and ortho-toluidine blue from J. T. Baker Chemical Co., N. Phillipsburg, N. J.; ellagic acid from $\mathrm{K}$. and $\mathrm{K}$. Laboratories, Jamaica, N. Y. and stearic acid from Price, Bromborough Pool, New Ferry, England. All of these were tested at concentrations from $10 \mu \mathrm{g}$ to $10 \mathrm{mg} / \mathrm{ml}$ in buffered saline, except heparin, which was tested over a range of $1-10 \mathrm{U} / \mathrm{ml}$, and sodium stearate and ellagic acid which were tested at the concentrations shown in Table IV. Hageman factor was prepared as described by Ratnoff and Davie (8). Using the definition proposed by Ratnoff and Davie (8) that $1 \mathrm{U}$ of Hageman factor is the amount of activity present in $1 \mathrm{ml}$ of pooled normal human plasma, the preparations used had a specific activity of $6-10$.

A screening test for inhibition of the contact stages was carried out as follows: $0.1 \mathrm{ml}$ volumes of normal plasma, the test substance, and cephalin were sequentially added to a silicone-treated test tube. After $30 \mathrm{sec}$, incubation at $37^{\circ} \mathrm{C}, 0.1 \mathrm{ml}$ of Celite suspension $(20 \mathrm{mg} / \mathrm{ml}$ of buffered saline) was added and the tube was agitated intermittently. Exactly $60 \mathrm{sec}$ after adding the Celite, the mixture was recalcified with $0.1 \mathrm{ml}$ of $0.025 \mathrm{M} \mathrm{CaCl}_{2}$ and the time required to form a solid clot was recorded. The ability of activated PTA to neutralize any anticoagulant effect demonstrated by the test material was tested by adding the same reagents in the same sequence, except that 0.1 $\mathrm{ml}$ of Celite eluate (activated PTA) replaced the Celite suspension and the $\mathrm{CaCl}_{\mathbf{2}}$ was added immediately after the Celite eluate.

Celite eluates were prepared and tested, as previously described (5), with minor modifications. Unless otherwise specified, $0.1 \mathrm{ml}$ of test reagent was added to $4 \mathrm{mg}$ of Celite in a silicone-treated $10 \times 75 \mathrm{~mm}$ test tube. After $5 \mathrm{~min}$ incubation at $37^{\circ} \mathrm{C}, 1 \mathrm{ml}$ of citrated noncontact plasma was added and the tube inverted every 2 min for $10 \mathrm{~min}$ at $37^{\circ} \mathrm{C}$. The Celite was separated by centrifugation, the supernatant fluid was decanted, and the Celite was washed three times with distilled water. The Celite eluted with $2 \mathrm{ml}$ of $1.71 \mathrm{~m}$ saline buffered with barbital acetate at $\mathrm{pH}$ 7.40. The elution was carried out for $10 \mathrm{~min}$ at $37^{\circ} \mathrm{C}$, the Celite was separated by centrifugation, and the supernatant fluid was dialysed overnight against $0.145 \mathrm{M}$ buffered saline. Eluate activity was measured by acceleratory effect on the clotting time of normal noncontact plasma $(5,9)$. The clotting mixtures were $0.1 \mathrm{ml}$ of normal noncontact plasma, $0.1 \mathrm{ml}$ of cephalin, incubated for $1 \mathrm{~min}$ at $37^{\circ} \mathrm{C}, 0.1 \mathrm{ml}$ of eluate diluted in $0.145 \mathrm{M}$ buffered saline, and $0.1 \mathrm{ml}$ of $0.025 \mathrm{M} \mathrm{CaCl}_{2}$. The clotting times were plotted against dilution on double logarithmic paper and the activity of the test eluate expressed as a percentage of that of the control eluate. The activated PTA preparations used were Celite eluates made from normal citrated plasma $(5,9,10,11)$. This preparation probably contains some activated Hageman factor activity as well as activated PTA, but is free from other known clotting factors.

The protein concentration of the activated PTA preparation was $0.36 \mathrm{mg} / \mathrm{ml}$. Hageman factor was measured by a previously described method (5) that is similar to the method described by Ratnoff and Davie (8). The clotting mixture consisted of the following reagents added sequentially : $0.1 \mathrm{ml}$ volumes of Hageman-deficient plasma, test solution diluted in citrate-saline, cephalin ( 1 volume of $4 \%$ trisodium citrate to 5 volumes of $0.145 \mathrm{~m}$ saline), and Celite $(20 \mathrm{mg} / \mathrm{ml})$; after $1 \mathrm{~min}$ incubation at $37^{\circ} \mathrm{C}$, $0.1 \mathrm{ml}$ of $0.050 \mathrm{M} \mathrm{CaCl}_{2}$ was added and the clotting time measured. The clotting time was plotted against the dilution of the test solution on double logarithmic paper and the activity of the test solution calculated as a percentage of the control solution, which was usually pooled normal citrated plasma. PTA, PTC, and antihemophilic factors were tested for in exactly the same way as Hageman factor, except that the appropriate substrate plasma from a congenitally deficient subject was substituted for Hageman-deficient plasma.

Protein concentration was measured as described by Lowry, Rosebrough, Farr, and Randall (12). Dialysis was carried out with constant stirring for $16 \mathrm{hr}$ at $4^{\circ} \mathrm{C}$, using $4 / 32^{\prime \prime}$ flat-width dialyzer tubing.

The skin contact experiment was carried out as previously described (19). $0.01 \mathrm{ml}$ of cytochrome $c(10 \mathrm{mg} / \mathrm{ml})$ or saline was layered on an $8 \mathrm{~mm}$ diameter area of skin and $0.09 \mathrm{ml}$ of solution was added to the plasma, which was incubated in contact with the skin for $1 \mathrm{~min}$ before adding cephalin and calcium and timing the formation of a solid clot.

\section{RESULTS}

Screening test for inhibition of the contact phase of blood coagulation. In this test, inhibitory activity of the test material is studied in a Celite- 
activated partial thromboplastin time system in which the initial reactions are activation of the Hageman and PTA factors by Celite.

Anticoagulant effect resulting from interposing the test substance between the Celite and plasma may be due to inhibition of any stage of the clotting process. It is suggested that $(a)$ if the anticoagulant effect is neutralized when activated PTA is substituted for Celite, inhibition of the contact stages is likely, since activated PTA bypasses these stages specifically; $(b)$ if activated PTA significantly reduces the anticoagulant effect without restoring the clotting time to the normal range, it is likely that the anticoagulant is active against the later stages of coagulation as well as the contact stages; and $(c)$ if activated PTA does not neutralize anticoagulant activity, only the later stages are affected.

When protamine sulfate was tested, concentrations up to $0.02 \mathrm{mg} / \mathrm{ml}$ inhibited the clotting of plasma activated by Celite or plasma activated by
PTA (Fig. 1 $a$ ). With higher concentrations of protamine there was partial reversal of the anticoagulant effect in the presence of activated PTA but progressive prolongation of the clotting time of Celite-activated plasma. Substances which inhibit the clotting of Celite-activated plasma are listed in Table I. Ortho-toluidine blue, cetyl trimethylammonium bromide, methylene blue, hexadimethrine, protamine sulfate, polylysine, and polyornithine markedly prolonged the clotting of plasma activated by Celite or by activated PTA; whereas spermine, cytochrome $c$, ribonuclease, and lysozyme inhibit the clotting of Celite-activated plasma specifically (Fig. $1 b$, Table I). Trasylol and hydroxychloroquine sulfate moderately inhibited the clotting of Celite-activated plasma. Substances without significant inhibitory effect included arginine, lysine, $\alpha$-chymotrypsinogen, trypsinogen, and Cohn fractions I, II, III, IV-1, IV-4, and $\mathrm{V}$.

Further experiments based on the Celite eluate

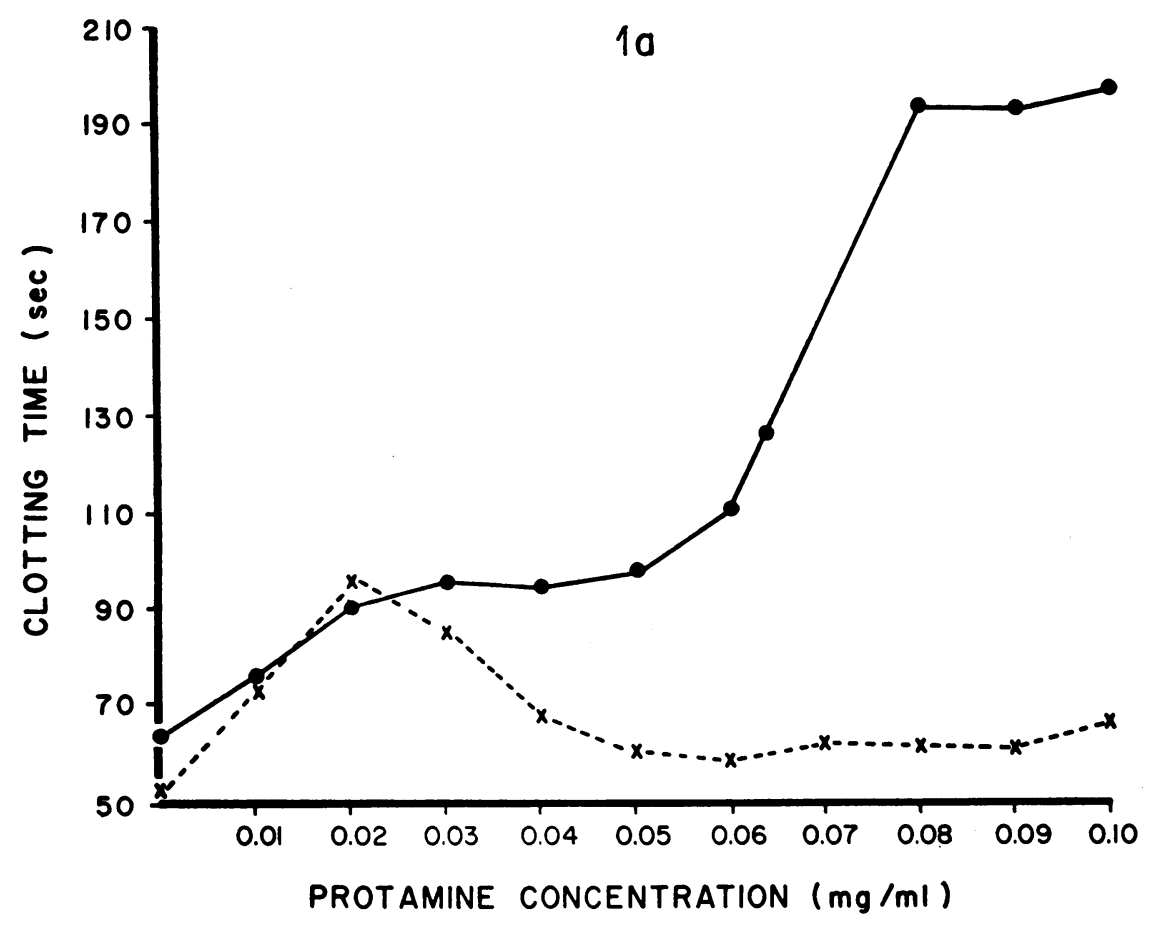

FIGURE $1 a$ Screening test for inhibitors of the contact phase of blood coagulation. The effect of protamine sulfate. The tests were carried out in silicone-treated tubes at $37^{\circ} \mathrm{C}$. The clotting mixtures were made as follows: $-0=0.1 \mathrm{ml}$ of plasma, 0.1 $\mathrm{ml}$ of protamine sulfate or saline, $0.1 \mathrm{ml}$ of cephalin, $30 \mathrm{sec}$ at $37^{\circ} \mathrm{C} ; 0.1 \mathrm{ml}$ of Celite $(20 \mathrm{mg} / \mathrm{ml}), 60 \mathrm{sec}$ at $37^{\circ} \mathrm{C} ; 0.1 \mathrm{ml}$ of $\mathrm{CaCl}_{2}(0.025 \mathrm{~mole} /$ liter $) . \times-\times=0.1 \mathrm{ml}$ of Celite eluate replaces Celite and $\mathrm{CaCl}_{2}$ is added without further delay. 


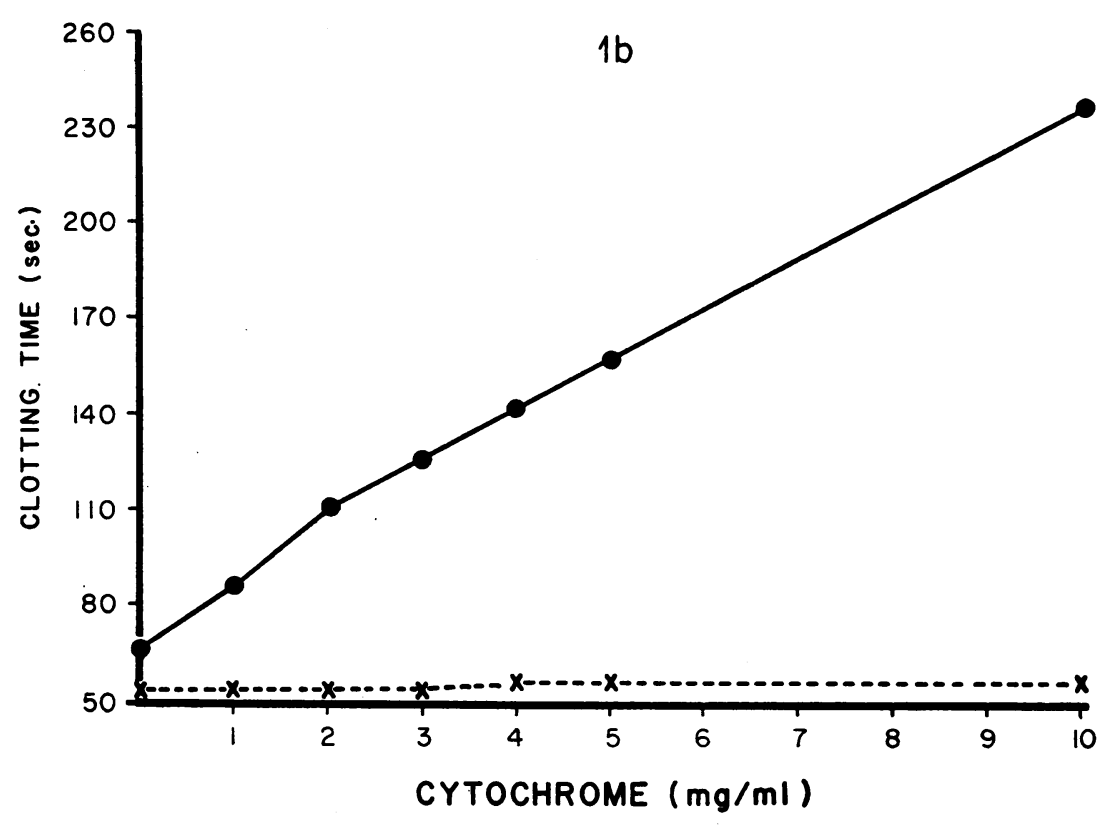

FIgURE $1 b$ Cytochrome $c$ replaces protamine sulfate.

TABLE I

Substances Which Inhibit Celite Activation of Coagulation

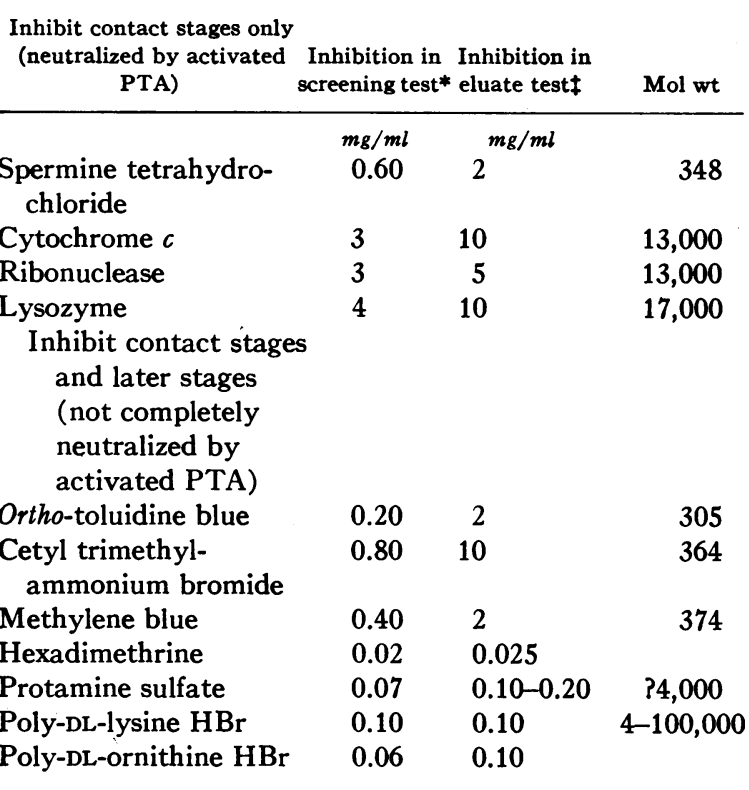

* Inhibition in the screening test is defined as that concentration of the substance that prolongs the Celite-activated clotting time $60 \mathrm{sec}$ or more than the clotting time in the presence of Celite eluate.

$\ddagger$ Inhibition in the eluate test is defined as that concentration of the substance that causes $90 \%$ or more reduction in the formation of Celite eluate activity. test were carried out to determine the mechanism of inhibition of the surface-activated stages of coagulation. When normal citrated plasma is exposed to Celite, the Hageman and PTA factors are selectively activated and adsorbed to the Celite which is separated from the plasma by centrifuga-

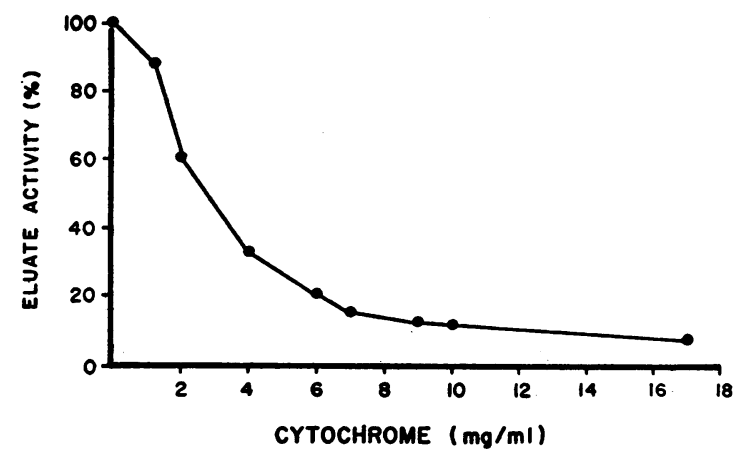

FIGURE 2 The activity of Celite eluates made from plasma added to mixtures of a constant amount of Celite and varying concentrations of cytochrome. The eluates were made as follows: to $4 \mathrm{mg}$ of Celite in a siliconetreated tube, $0.1 \mathrm{ml}$ of cytochrome was added. $1 \mathrm{ml}$ of normal citrated plasma was added to each tube and the contents were mixed and incubated at $37^{\circ} \mathrm{C}$ for $10 \mathrm{~min}$ with mixing by inversion every $2 \mathrm{~min}$. Celite eluates were then prepared and tested as previously described. When $0.1 \mathrm{ml}$ of cytochrome $(20 \mathrm{mg} / \mathrm{ml})$ was added after the Celite had been incubated with plasma, an eluate of $100 \%$ activity was recovered.

Inhibition of Hageman Factor Activation 


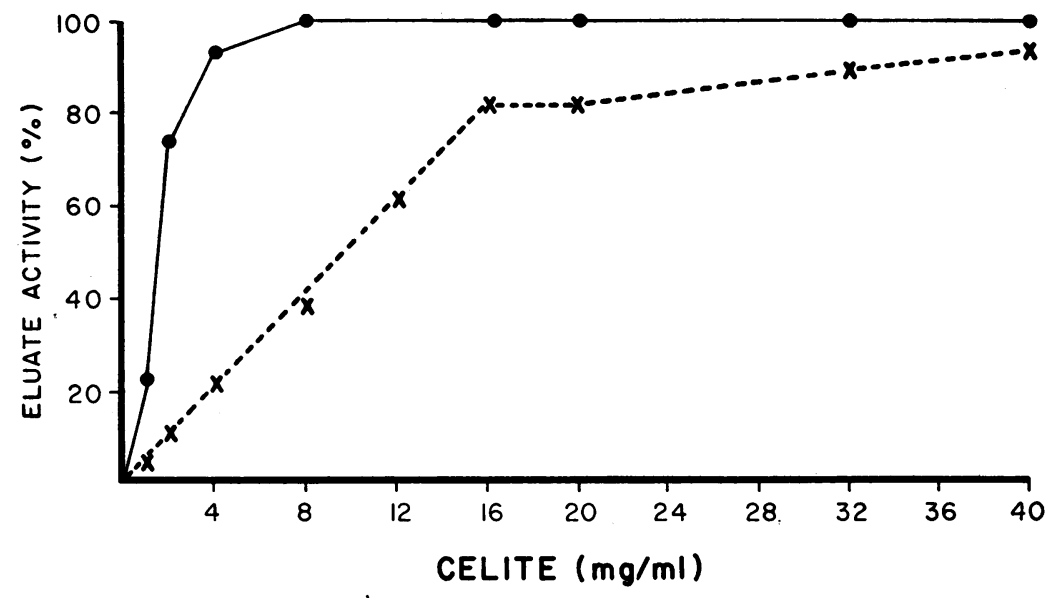

Figure 3 The activity of Celite eluates made from plasma added to mixtures of varying amounts of Celite and a constant concentration of cytochrome. $0.4 \mathrm{ml}$ of $4 \mathrm{mg} / \mathrm{ml}$ cytochrome was added to Celite. $1 \mathrm{ml}$ of plasma was added and eluates were made and tested $(X-\times) .0 .4 \mathrm{ml}$ of buffered saline replaced cytochrome (-๑).

tion. Activated PTA is eluted from the Celite with hypertonic saline and the technique makes it possible to study the contact stages separately from the later stages of coagulation $(5,10)$.

Specific test for inhibition of the contact stages of blood coagulation. Cytochrome added to Celite prevented the formation of activated PTA when plasma was subsequently added and eluates prepared (Fig. 2). No inhibition resulted when plasma and Celite were preincubated before adding cytochrome, indicating that cytochrome inhibits Celite-plasma interaction. The inhibitory effect of cytochrome can be almost completely overcome by inhibitory.

excess Celite (Fig. 3). Positively charged substances that inhibited the formation of activated PTA are listed in Table I. Negatively charged substances such as insulin and heparin did not inhibit activated PTA formation. Arginine, lysine, $\alpha$-chymotrypsinogen, trypsinogen, and Cohn fractions I, II, III, IV-1, IV-4, and V were also not

In the next experiment, Hageman factor, PTA factor, and cytochrome were added to Celite in different sequence, eluates were prepared, and coagulant activity measured. When cytochrome addition preceded Hageman factor, complete inhibition resulted, whereas practically no inhibition occurred when cytochrome addition followed Hageman factor (Table II).

Lysozyme and ribonuclease produced similar effects to cytochrome, but when protamine or spermine were substituted for cytochrome in the experiment described in Table II, significant inhibi-

\section{TABLE II}

Effect of the Addition of Cytochrome on Stages in the Formation of Activated Factor XI*

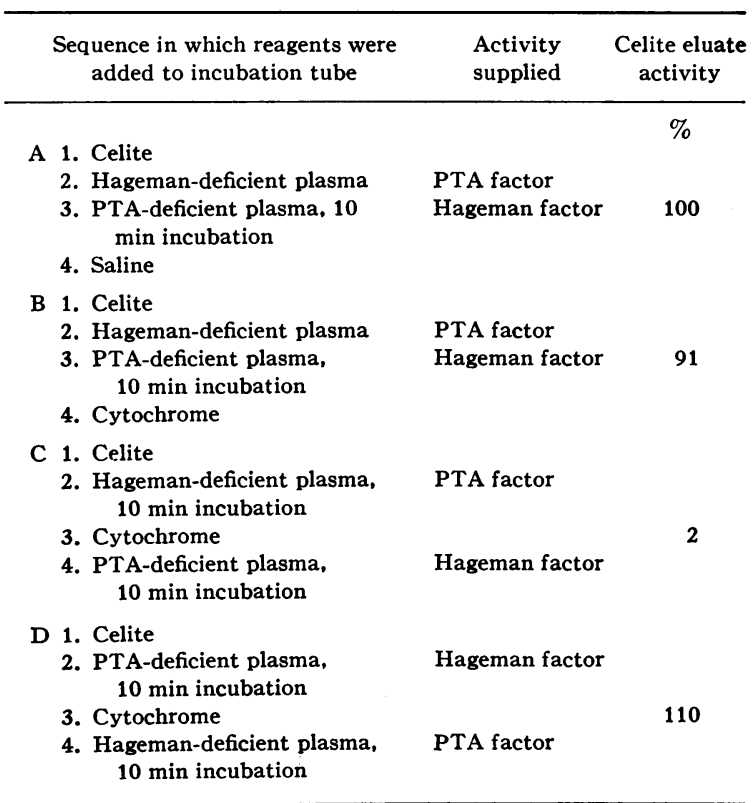

* Silicone-treated incubation tubes were used. The incubation mixtures consisted of $4 \mathrm{mg}$ of Celite, $0.5 \mathrm{ml}$ of Hageman factor-deficient plasma, $0.5 \mathrm{ml}$ of PTA factor-deficient plasma, and $0.1 \mathrm{ml}$ of cytochrome $c$ $(10 \mathrm{mg} / \mathrm{ml})$ or buffered saline. After the stated incubation periods at $37^{\circ} \mathrm{C}$ the Celite wasłdeposited by centrifugation, washed, eluted, and the eluates dialysed and tested. 
tion resulted when the test substance was added after Hageman factor.

It was thought that cytochrome might be adsorbed to the surface of Celite and prevent Hageman factor adsorption. Cytochrome was added to Celite, the Celite washed 10 times with distilled water, plasma was added, and an eluate made.

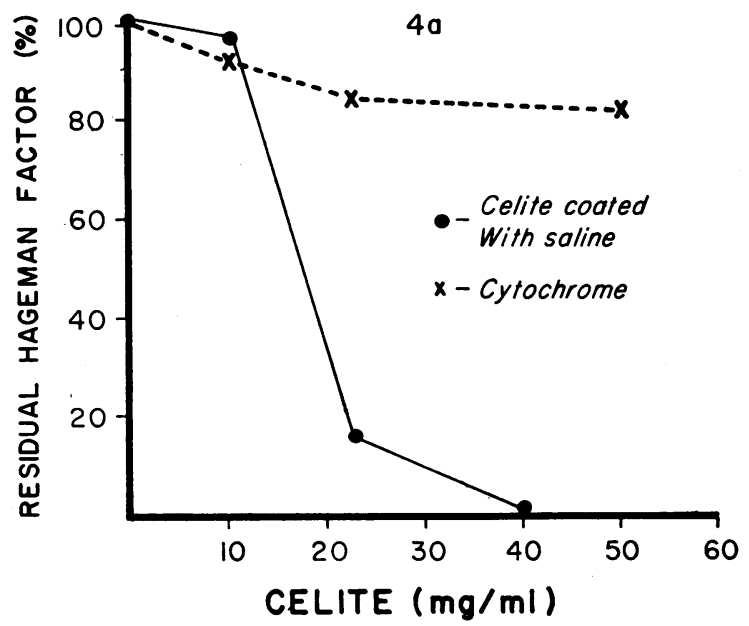

FIgURe $4 a$ Residual Hageman factor activity in Hageman factor preparations exposed to Celite coated with cytochrome. Different quantities of Celite were coated with $0.1 \mathrm{ml}$ of cytochrome $(10 \mathrm{mg} / \mathrm{ml})$. The Celite was washed three times with $10 \mathrm{ml}$ of distilled water. $1-\mathrm{ml}$ aliquot of Hageman factor was mixed with the Celite for $10 \mathrm{~min}$ at $37^{\circ} \mathrm{C}$. The Celite was deposited by centrifugation and the activity of the supernatant Hageman factor solution was measured. PTA-deficient plasma was used as a source of Hageman factor.
TABLE III

Effect of Cytochrome on the Clotting Time of Plasma in the Presence of Thrombin or Brain Thromboplastin*

\begin{tabular}{|c|c|c|}
\hline \multirow[b]{2}{*}{ Addition } & Saline & Cytochrome \\
\hline & \multicolumn{2}{|c|}{ Clotting time } \\
\hline & & sec \\
\hline Thrombin & 19.2 & 20.0 \\
\hline \multicolumn{3}{|c|}{ Thromboplastin, $\mu \mathrm{g} / \mathrm{ml}$} \\
\hline 4000 & 14.9 & 14.9 \\
\hline 1000 & 16.4 & 16.3 \\
\hline 250 & 19.9 & 20.0 \\
\hline 62 & 31.3 & 31.6 \\
\hline 16 & 47.2 & 50.3 \\
\hline 4 & 93.7 & 96.0 \\
\hline
\end{tabular}

* $0.1 \mathrm{ml}$ of citrated plasma and $0.1 \mathrm{ml}$ of buffered saline or cytochrome $(10 \mathrm{mg} / \mathrm{ml})$ were mixed and incubated at $37^{\circ} \mathrm{C}$ for $30 \mathrm{sec} .0 .1 \mathrm{ml}$ of thrombin $(10 \mathrm{U} / \mathrm{ml})$ or $0.1 \mathrm{ml}$ of brain thromboplastin and $0.1 \mathrm{ml}$ of $0.025 \mathrm{M} \mathrm{CaCl}_{2}$ were added and the clotting time measured.

Eluates made from Celite treated in this way had reduced coagulant activity.

Inhibition of Hageman factor adsorption. Complete removal of Hageman factor from PTAdeficient plasma resulted from adsorption with 40 $\mathrm{mg}$ of Celite per $\mathrm{ml}$ of plasma, and from the partially purified Hageman factor fraction by adsorption with $2 \mathrm{mg}$ of Celite per $\mathrm{ml}$ of solution. Prior coating of the Celite with cytochrome markedly inhibited adsorption from plasma or fraction (Fig. 4). Coating of the Celite with ribonuclease,

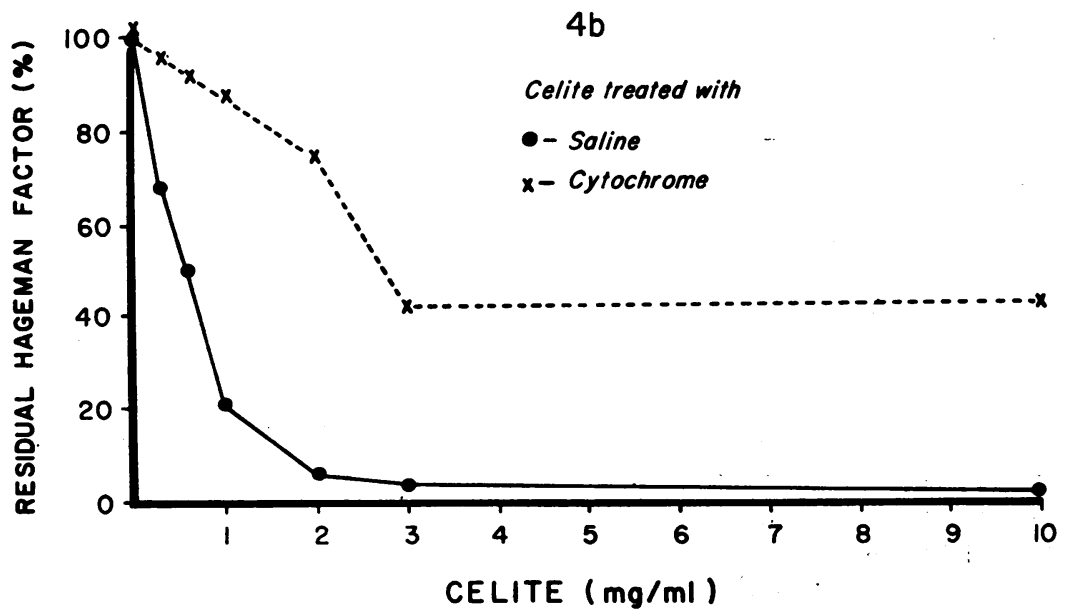

FIGURE $4 b$ Similar experiment to that described in legend to Fig. $4 a$, except that the source of Hageman factor was a purified Hageman factor solution with $1 \mathrm{U} / \mathrm{ml}$ activity and $165 \mu \mathrm{g} / \mathrm{ml}$ protein concentration. 
TABLE IV

Effect of Cytochrome on the Clot-Promoting Activity of Different Activators of the Hageman and PTA Factors*

\begin{tabular}{|c|c|c|}
\hline \multirow[b]{2}{*}{ Activator } & Saline & Cytochrome \\
\hline & \multicolumn{2}{|c|}{ Clotting time } \\
\hline & $\sec$ & sec \\
\hline $\begin{array}{l}\text { Celite } \\
\qquad 20 \mathrm{mg} / \mathrm{ml}\end{array}$ & 44 & 123 \\
\hline $\begin{array}{l}\text { Kaolin, } \\
5 \mathrm{mg} / \mathrm{ml}\end{array}$ & 43 & 74 \\
\hline $\begin{array}{l}\text { Sodium stearate, } \\
\qquad 3 \times 10^{-3} \mathrm{mEq} / \mathrm{ml}\end{array}$ & 80 & 281 \\
\hline $\begin{array}{l}\text { Ellagic acid, } \\
\quad 3.3 \times 10^{-3} \mathrm{mg} / \mathrm{ml}\end{array}$ & 66 & 351 \\
\hline Skin & 116 & 203 \\
\hline No activator & 369 & 372 \\
\hline
\end{tabular}

* The clotting mixtures were made by sequentially adding $0.1 \mathrm{ml}$ volumes of activator, saline or cytochrome, and plasma. After $1 \mathrm{~min}$ incubations at $37^{\circ} \mathrm{C}, 0.1 \mathrm{ml}$ volumes of cephalin and $0.025 \mathrm{M} \mathrm{CaCl}_{2}$ were added. The experiments with skin contact and without an activator were carried out at $25^{\circ} \mathrm{C}$.

spermine, or lysozyme significantly inhibited Hageman factor adsorption from PTA-deficient plasma.

Effect of cytochrome on other stages of coagulation. Cytochrome had negligible effect on the

TABLE V

Inhibitory Effect of Polylysine Polymers*

\begin{tabular}{|c|c|c|c|c|c|}
\hline \multicolumn{6}{|c|}{ Polymer mol wt } \\
\hline \multicolumn{2}{|c|}{$2000-6000(4000)$} & \multicolumn{2}{|c|}{$30,000-50,000(40,000)$} & \multicolumn{2}{|c|}{$\begin{array}{c}80,000-120,000 \\
(100,000)\end{array}$} \\
\hline $\begin{array}{r}\mu \mu \text { mole } \\
\times 10^{-1}\end{array}$ & inhibition & $\begin{array}{r}\mu \mu \text { mole } \\
\times 10^{-1}\end{array}$ & inhibition & $\begin{array}{r}\mu \mu \text { mole } \\
\times 10^{-1}\end{array}$ & inhibition \\
\hline & $\%$ & & $\%$ & & $\%$ \\
\hline 500 & 96 & 50 & 97 & 20 & 96 \\
\hline 375 & 95 & 37.5 & 95 & 15 & 91 \\
\hline 250 & 91 & 25 & 92 & 10 & 87 \\
\hline 125 & 79 & 12.5 & 75 & 5 & 74 \\
\hline 25 & 11 & 2.5 & 31 & 1 & 16 \\
\hline
\end{tabular}

* Inhibitory activity was measured as follows: $0.1 \mathrm{ml}$ of test solution was added to $4 \mathrm{mg}$ of Celite in a siliconetreated tube. After $5 \mathrm{~min}$ at $37^{\circ} \mathrm{C}, 1 \mathrm{ml}$ of plasma was added; after an additional $10 \mathrm{~min}$ at $37^{\circ} \mathrm{C}$ the Celite was deposited by centrifugation, the supernatant plasma was discarded; and the Celite, washed three times with distilled water, and eluted with $2 \mathrm{ml}$ of $1.71 \mathrm{~m}$ saline. After dialysis the eluates were tested and the degree of reduction in activity recorded as per cent of inhibition. thrombin or prothrombin clotting time of normal plasma (Table III).

Effect of cytochrome on other activators of Hageman and PTA factors. Cytochrome inhibited the clot-promoting activity of kaolin, sodium stearate, ellagic acid, and human skin (Table IV). Spermine, ribonuclease, and lysozyme similarly inhibited the clot-promoting effect of the various activators.

Effect of different size polylysine polymers on activated PTA formation. The inhibitory effect of three polylysine polymers on activated PTA formation is shown in Table V. Inhibitory activity appeared to be almost directly proportional to molecular weight at the three molecular weights tested (4000, 40,000, and 100,000).

\section{DISCUSSION}

From the data recorded in Figure $1 a$ it seems likely that concentrations of protamine sulfate above $0.02 \mathrm{mg} / \mathrm{ml}$ inhibit the contact stages of coagulation, as suggested by Haanen et al. (4). However, they also affect later stages, in accordance with the observations of Breckenridge and Ratnoff (13) who showed that protamine inhibits the action of activated factor $\mathrm{X}$, and the observations of Shanberge and Fukui (14) who indicated that factor IX activation was inhibited. The reversal of the anticoagulant effect at high concentrations of protamine (Fig. 1 $a$ ) may be due to a procoagulant effect on the thrombin-fibrinogen reaction. In view of the complex effect produced by protamine, most of the studies were carried out with cytochrome $c$, which appears to inhibit the contact stages specifically.

Cytochrome $c$ prolongs the clotting time of Celite-activated plasma and since the anticoagulant effect is abolished by substitution of activated PTA for Celite, it is suggested that the action of cytochrome is confined to the contact stages of coagulation. This suggestion is supported by the lack of effect on the thrombin and one-stage prothrombin times and the finding that cytochrome added to Celite prevents the formation of activated PTA when plasma is subsequently added. The precise stage at which cytochrome acts is indicated by the results of the experiment shown in Table II. Cytochrome had no inhibitory effect when added to Celite preincubated with Hageman factor, but completely prevented PTA activation when added 
to Celite before adding Hageman factor. Cytochrome therefore inhibits a reaction between Celite and Hageman factor, but not between activated Hageman factor and PTA factor. A possible explanation of these findings is that cytochrome prevents adsorption of Hageman factor by Celite and this suggestion is confirmed by the results of the experiments shown in Fig. 4. It is inferred that activation of Hageman factor is prevented by blocking of adsorption. Because cytochrome inhibits the coagulant activity of all the Hageman factor activators tested, it is further inferred that adsorption of Hageman factor to the activator is essential for activation. Precisely how adsorption of Hageman factor leads to activation is uncertain. The only evidence on the question has been provided by Donaldson and Ratnoff (15) who reported that activation of purified Hageman factor resulted in increased sedimentation on a sucrose density gradient. Activation of Hageman factor in whole plasma was however not accompanied by altered sedimentation.

The nature of the forces binding the Hageman molecule to the activator are unknown, but some suggestion may be made about the activator binding sites. All the substances inhibiting the contact stages of coagulation are positively charged, and negatively charged substances such as heparin (4, 16) and insulin did not inhibit the contact stages. The inhibitors varied in molecular size as indicated by molecular weights ranging from $305-100,000$. The results of testing the polylysine polymers indicated that inhibitory activity is a function of size, as indicated by molecular weight over the range of 4000-100,000. Lysine itself was inactive which indicated that a minimum size is required for inhibitory activity. From these data it is suggested that the positively charged substances cover negatively charged sites on the Celite surface, and since several positively charged substances inhibit the coagulant activity of all the Hageman activators tested, it is likely that negatively charged sites are critical to Hageman factor adsorption and activation. These inferences are in agreement with the findings of Hubbard and Lucas (17), who measured surface negative charge area with the use of $\mathrm{Ag}\left(\mathrm{NH}_{3}\right)_{2}{ }^{+}$and $\mathrm{Br}^{-}$. Hageman and PTA factor activators such as kaolin, collagen, stearic acid, and live skin were all found to absorb Ag$\left(\mathrm{NH}_{3}\right)_{2}{ }^{+}$and were consequently thought to have considerable negative surface charge. The data and inferences also correlate with the findings of Margolis (3), who reported a correlation between clotpromoting activity and ability to adsorb the positively charged dye toluidine blue. One may suspect that any sufficiently positively charged substance above a minimum critical size will inhibit Hageman factor adsorption and activation. In support of this suggestion, spermine, ribonuclease, and lysozyme gave qualitatively similar results to cytochrome when tested in the experiments described in Table II and Fig. $4 \mathrm{a}$. A possible explanation for the difference in the results recorded in Figs. $4 \mathrm{a}$ and $4 \mathrm{~b}$ is that normal plasma contains substances which inhibit Hageman factor adsorption, and presumably, activation. Ratnoff and Rosenblum (20) specifically suggested that normal plasma contains an inhibitor of Hageman factor activation and Hageman factor-deficient plasma has been shown to inhibit Hageman factor activation by these workers and by others $(4,5,21,22)$. In order to establish the presence of such an inhibitor in normal plasma, it would be necessary to isolate inhibitory activity from normal plasma.

Hageman factor has a number of biological activities besides initiating coagulation ( 3 ). Ratnoff and Rosenblum (20) showed that protamine sulfate and hexadimethrine bromide inhibited the induction of increased capillary permeability in guinea pig skin by activated Hageman factor. Their experiments may also have reflected an effect upon activation, but this is unclear from the data presented.

Eisen (18) has provided evidence that hexadimethrine bromide inhibits surface-induced plasma kinin formation, hydrolysis of $p$-tosyl- $l$-arginine methyl ester, and fibrinolysis. It is suggested that the inhibitors described above may inhibit the induction of capillary permeability-inducing activity, plasma kinin formation, and fibrinolysis (23) by glass and similar surfaces.

\section{ACKNOWLEDGMENT}

This work was supported in part by research grants HE 10999 and HE 05741 from the National Institutes of Health.

\section{REFERENCES}

1. Ratnoff, O. D. 1966. The biology and pathology of the initial stages of blood coagulation. Progr. Hematol. 5: 204 .

Inhibition of Hageman Factor Activation 
2. Vroman, L. 1967. Surface activity in blood coagulation. In Blood Clotting Enzymology. W. H. Seegers, editor. Academic Press Inc., New York. 279.

3. Margolis, J. 1963. The interrelationship of coagulation of plasma and release of peptides. Ann. N. Y. Acad. Sci. 104: 133.

4. Haanen, C., F. Hommes, and G. Morselt. 1961. Some observations on the role of Hageman factor in blood coagulation. Thromb. Diath. Haemorrhag. 6: 261.

5. Nossel, H. L. 1964. The Contact Phase of Blood Coagulation. Blackwell Scientific Publications, Oxford, England.

6. Bell, W. N., and H. G. Alton. 1954. A brain extract as a substitute for platelet suspensions in the thromboplastin generation test. Nature. 174: 880 .

7. Biggs, R., and R. G. Macfarlane. 1962. Human Blood Coagulation and its Disorders. Blackwell Scientific Publications, Oxford, England. 3rd edition.

8. Ratnoff, O. D., and E. W. Davie. 1962. The purification of activated Hageman factor (activated Factor XII). Biochemistry. 1: 967.

9. Nossel, H. L., J. Niemetz, R. S. Mibashan, and W. G. Schulze. 1966. The measurement of Factor XI (plasma thromboplastin antecedent). Diagnosis and therapy of the congenital deficiency state. Brit. J. Haematol. 12: 133.

10. Waaler, B. A. 1959. Contact activation in the intrinsic blood clotting system. Studies on a plasma product formed on contact with glass and similar surfaces. Scand. J. Clin. Lab. Invest. 37 (11, Suppl): 1.

11. Niemetz, J., and H. L. Nossel. 1967. Method of purification and properties of anti-XIa (inhibitor of the contact product). Thromb. Diath. Haemorrhag. 17: 335.

12. Lowry, O. H., N. J. Rosebrough, A. L. Farr, and R. J. Randall. 1951. Protein measurement with the Folin phenol reagent. J. Biol. Chem. 193: 265.

13. Breckenridge, R. T., and O. D. Ratnoff. 1965. The role of proaccelerin in blood coagulation. Evidence that proaccelerin is converted to a prothrombinconverting principle by activated Stuart factor: with notes on the anticoagulant action of soybean trypsin inhibitor, protamine sulfate, and hexadimethrine bromide. J. Clin. Invest. 44: 302.

14. Shanberge, J. N., and H. Fukui. 1967. Studies on the anticoagulant action of heparin, protamine and polybrene in the activation of Factor IX. J. Lab. Clin. Med. 69: 927.

15. Donaldson, V. H., and O. D. Ratnoff. 1965. Hageman factor: alterations in physical properties during activation. Science. 150: 754.

16. Bloom, A. L. 1962. The contact phase of coagulation in the presence of heparin. J. Clin. Pathol. 15: 508.

17. Hubbard, O., and G. L. Lucas. 1960. Ionic charges of glass surfaces and other materials, and their possible role in the coagulation of blood. J. Appl. Physiol. 15: 265 .

18. Eisen, V. 1964. Effect of hexadimethrine bromide on plasma kinin formation, hydrolysis of $p$-tosyl- $l$ arginine methyl ester and fibrinolysis. Brit. J. Pharmacol. 22: 87.

19. Nossel, H. L. 1966. Activation of Factors XII (Hageman) and XI (PTA) by skin contact. Proc. Soc. Exptl. Biol. Med. 122: 16.

20. Ratnoff, O. D., and J. M. Rosenblum. 1958. Role of Hageman factor in the initiation of clotting by glass. Evidence that glass frees Hageman factor from inhibition. Am. J. Med. 25: 160.

21. Soulier, J. P., O. Wartelle, and D. Menache. 1959. Hageman trait and PTA deficiency: the role of contact of blood with glass. Brit. J. Haematol. 5: 121.

22. Hardisty, R. M., and J. Margolis. 1959. The role of Hageman factor in the initiation of blood coagulation. Brit. J. Haematol. 5: 203.

23. Iatridis, S. G., and J. H. Ferguson. 1962. Active Hageman factor: a plasma lysokinase of the human fibrinolytic system. J. Clin. Invest. 41: 1277. 